\title{
組織再生技術と創薬研究への応用
}

\author{
八木清仁

\section{Tissue Regeneration Technologies and the Application to Drug Development Researches}

\author{
Kiyohito YAGI \\ Graduate School of Pharmaceutical Sciences, Osaka University, \\ 1-6 Yamada-oka, Suita City 565-0871, Japan
}

近年，胚性幹細胞（ES 細胞）を始めとして様々 な幹細胞の存在が報告され，その旺盛な増殖能と多 分化能を疾病の治療に応用しようとする再生医療が 注目を集めている. ES 細胞は無限の増殖能と生体 に存在するあらゆる細胞に分化可能であり，移植し た際に生ずるテラトーマ形成の問題が解消されれば 万能細胞として再生医療の最も有力な細胞源となり 得る。また成体には有限ではあるが高い増殖能と胚 葉を超えた分化能を有する間葉系幹細胞 (MSC) が存在し，有用な細胞源として期待されている. MSC は骨髄中に存在し骨, 軟骨, 脂肪, 筋肉の細 胞へ分化することが知られていたが, 最近肝細胞, 神経細胞へも分化誘導が可能であることが示され た. 患者自身のMSCを用いれば免疫拒絶の起こら ない治療が可能であることが ES 細胞に比べ優れて おり, 骨髄以外に脂肪組織, 歯髄, 臍帯血などから MSC が単離され再生医療への適用が検討されてい る.さらには近い将来, MSC などの幹細胞を用い て種々の臟器, 組織が生体外で構築可能となる時代 がくるかもしれない.

Tissue Engineering（組織工学）の領域において は再生医療, バイオ人工臓器に必要な細胞の生存性 をいかに維持し, 機能を最大限に発揮させるかが重 要な鍵となっている，足場依存性の細胞は接着する 基材によって生存性，増殖能，機能が大きく影響を 受け, 組織再生においては単に平面培養を行うだけ では目的が達成されない場合が多く，「三次元培養」 が重要なキーワードとなっている，三次元的な細胞

大阪大学大学院薬学研究科（干565-0871 吹田市山田丘 1-6)

e-mail: yagi@phs.osaka-u.ac.jp

日本薬学会第 127 年会シンポジウム S45 序文
間相互作用を再現することにより生体内により近い 状態及び環境の構築が重要と考えられている。 しか も生体の組織をさらに模倣することを目指し，複数 種類の細胞を三次元的に培養することにより生体外 で機能的な組織を構築する技術が開発されている.

上述の組織再生技術はバイオ人工藏器開発に有用 と認識されてはいたが, 薬学領域では特にこれまで 取り上げられることなく年会のシンポジウムとして も企画されることはなかった。しかしながらヒトの 組織を模倣した組織再生が可能であれば薬効評価, 薬物代謝予測等, 創薬研究に重要なツールとなり得 ることから今後動物実験に替わり得るシステムとし て有望であると考えている.

本号に掲載されている総説は第 127 年会（富山） において開催されたシンポジウム「組織再生の先端 技術とその創薬研究への応用」の講演者がその内容 をまとめたものである．以下にその要約を示す．筆 者 (大阪大学) は通常廃棄される親知らずの歯胚組 織から MSC クローンを単離し, 肝再生医療への利 用が可能であることを紹介する，松崎 貴先生（島 根大学）は幹細胞を豊富に含む毛包を用いる毛の再 生技術と創薬への応用についてのアイデアを紹介す る. 井藤 彰先生（九州大学）は磁性ナノ粒子を用 いて種々の組織が三次元的に構築可能であることを 提示する. 酒井康行先生, 小森喜久夫先生（東京大 学）は動物実験代替法として肺，小腸，肝臓のモデ ル組織を構築し毒性評価系として用いることを提案 する. 渡邊昌俊先生（横浜国立大学）は前立腺がん 細胞の 3 次元培養モデルの作成とその特性解析を行 い, 抗がん剂に対する抵抗性獲得機構について考察 を行う. 内野 正先生 (国立医薬品食品衛生研究所) は樹状細胞，角化細胞，線維芽細胞を用いて新規な 
皮膚モデルを構築し皮膚アレルギー性を評価する動 物実験代替法の試夕を紹介する，竹澤俊明先生（農 業生物資源研究所）はご自身で開発されたコラーゲ ンビトリゲル薄膜を利用し創薬開発, 再生医療に有 用な三次元組織を構築する技術を紹介する.

独農業生物資源研究所の竹澤俊明先生と筆者が
オーガナイズし，国内で組織再生の最先端技術を開 発されている研究者に講演を依頼し, 薬学会として は新規なテーマのシンポジウムを行うに至った。本 企画が発展的に創薬研究に生かせればと期待してい る. 